\title{
KOHESI DAN KOHERENSI BAHASA INDONESIA DALAM KARANGAN MAHASISWA JURUSAN ASEAN STUDIES UNIVERSITAS WALAILAK THAILAND TAHUN 2016
}

\author{
Diah Ayu Puspitasari, Gatut Susanto \\ Universitas Negeri Malang
}

\section{A R T I K E L}

Kata Kunci:

piranti kohesi gramatikal

piranti kohesi leksikal

koherensi

\section{A RT I C LE IN F O}

\section{Keywords:}

grammatical cohesion device lexical cohesion device

coherence

\begin{abstract}
A B S T R A K
Penelitian ini bertujuan untuk mendeskripsikan penggunaan piranti kohesi dan koherensi pada karangan mahasiswa ASEAN Studies Universitas Walailak. Data penelitian ini berupa piranti kohesi dan koherensi dalam karangan mahasiswa ASEAN Studies. Berdasarkan analisis data, diperoleh dua hasil penelitian. Pertama, mahasiswa ASEAN Studies menggunakan beragam piranti kohesi gramatikal dan leksikal. Kedua, mahasiswa ASEAN Studies membentuk koherensi dalam karangannya dengan menghadirkan piranti kohesi, serta memunculkan hubungan parataksis yang ditunjukkan dengan penataan gagasan secara subordinatif.
\end{abstract}

\section{A B S T R A C T}

This study aims to describe the using of cohesion and coherence device in text of ASEAN Studies Walailak University student. Data consist of cohesion and coherence device that finded in the text that written by ASEAN Studies student. Base on data analysis there are two result. first ASEAN Studies student use many kind of grammatical cohesion device and lexical cohesion device. Second, ASEAN Studies student form coherention in the text with involving cohesion device and by showing parataksis relation. That parataksis relation form by constructing the idea with subordinatif construction.

(c) 2017 BASINDO Journal. All rights reserved

\section{PENDAHULUAN}

Kohesi dan koherensi memiliki peran yang penting dalam menyusun wacana yang baik. Kohesi dapat menjadikan bagian-bagian dalam sebuah wacana saling berkaitan. Dengan memperhatikan ketepatan penggunaan kohesi dan koherensi sebuah wacana tulis menjadi komunikatif dan mudah dipahami oleh pembaca. Halliday dan Hassan (1984:26) berpendapat kohesi adalah seperangkat hubungan makna yang secara umum mencakup seluruh informasi yang disampaikan dalam sebuah teks yang membedakan teks dengan "bukan teks" dan menghubungkan antar subtansi makna. Senada dengan pendapat tersebut Morris dan Flirts (dalam Ebrahimpourtaher dan Eissaei, 2013:63) menyatakan bahwa kohesi adalah hal penting yang menjadikan teks saling bergantung satu sama lain. Kohesi juga merupakan salah satu faktor yang menjadikan sebuah wacana koheren. Koherensi adalah kepaduan maknawi dalam sebuah wacana. Lauer et al. (dalam Palmer, 1999:63) mendefinisikan koherensi sebagai hal yang berkaitan dengan peletakan unsur-unsur bahasa pada posisi yang tepat dengan penghubung yang tepat.

Perhatian khusus terhadap penggunaan kohesi dan koherensi dalam pembelajaran menulis pebelajar BIPA merupakan hal yang penting. Hal tersebut didasarkan pada salah satu tujuan khusus pembelajaran BIPA menurut Kurniawan (2008:14) yaitu pebelajar memiliki kemampuan berbahasa Indonesia untuk kepentingan pengembangan ilmu, komunikasi, bisnis, dan profesi yang digelutinya. Untuk mencapai tujuan tersebut pebelajar BIPA memerlukan

\footnotetext{
${ }^{*}$ Corresponding author.

E-mail addresses: diah4yuP@gmail.com (Diah Ayu Puspitasari), gatutus@yahoo.com (Gatut Susanto)
} 
kemampuan komunikasi salah satunya komunikasi tulis yang baik. Kemampuan komunikasi tulis yang baik tersebut dapat dikembangkan dengan memperhatikan penggunaan kohesi dan koherensi.

Penelitian ini bertujuan untuk mendeskripsikan penggunaan piranti kohesi dan koherensi dalam karangan mahasiswa jurusan ASEAN Studies Universitas Walailak Thailand. Karangan mahasiswa ASEAN Studies Universitas Walailak dipilih sebagai sumber data penelitian karena dapat merepresentasikan seperti apa tingkat keterampilan berbahasa Indonesia pebelajar Bahasa Indonesia untuk Penutur Asing (BIPA) asal negara Thailand dengan tingkat menengah.

Penelitian dengan pebelajar BIPA asal Thailand sebagai subjek penelitian penting untuk dilakukan, mengingat jumlah pebelajar bahasa Indonesia asal Thailand semakin meningkat. Pemerintah Thailand memasukkan mata kuliah bahasa Indonesia sebagai salah satu mata kuliah yang harus di pelajari sebagai wujud usaha agar mahasiswa di Thailand menguasai bahasa Indonesia, sehingga mereka tidak terkendala komunikasi dalam bersaing di pasar bebas ASEAN. Surin (dalam Waenawe, 2013:01) menyatakan bahasa Indonesia adalah bahasa asing keempat yang dianggap penting di Thailand untuk tujuan pengembangan ekonomi pada tahun 2015.

Penelitian ini diharapkan memiliki kegunaan untuk pengajar BIPA sebagai bahan pertimbangan dalam menyusun Rencana Pelaksanaan Pembelajaran (RPP) yang sesuai dengan kebutuhan dan kemampuan pebelajar tingkat madya asal Thailand.

\section{METODE}

Penelitian ini dilakukan menggunakan pendekatan kualitatif. Hal pertama yang dilakukan oleh peneliti adalah mengumpulkan hasil karangan mahasiswa dari kegiatan menulis setiap akhir pembelajaran di kelas, atau pun karangan dalam lembar kerja ujian akhir semester. Kemudian, karangan yang telah terkumpul diseleksi dan dipilih yang memenuhi kriteria data. Kriteria pemilihan data meliputi, adanya identitas yang jelas, teks karangan minimal satu paragraf, dan tulisan karangan dapat terbaca. Data yang sesuai kriteria dimasukkan dalam format penampung data penggunaan piranti kohesi, lalu data yang tertampung dalam format penampung data penggunaan piranti kohesi dimasukkan ke dalam format penampung data penggunaan piranti koherensi sesuai dengan panduan pengumpulan data. Data yang terkumpul kemudian diberi catatan analisis sesuai dengan panduan analisis data.

Instrumen kunci penelitian ini adalah peneliti sendiri (human instrument) karena peneliti berperan dalam menetapkan fokus penelitian, memilih sumber data, melakukan pengumpulan data, analisis data, manafsirkan data, dan membuat kesimpulan atas temuan. Selain itu, peneliti menggunakan panduan dan tabel untuk memudahkan proses pengumpulan data. Panduan dan tabel tersebut meliputi: a) panduan pengumpulan data, (b) panduan analisis data, (c) tabel data, dan (d) tabel analisis data.

\section{HASIL \\ Paparan Piranti Kohesi yang Terdapat pada Karangan Bahasa Indonesia Mahasiswa ASEAN Studies Universitas Walailak}

Berdasarkan hasil analisis data, diperoleh data piranti kohesi yang digunakan dalam karangan mahasiswa ASEAN Studies berupa piranti kohesi gramatikal dan piranti kohesi leksikal sebagai berikut.

\section{1) Piranti Kohesi Gramatikal}

Bentuk-bentuk piranti kohesi gramatikal dalam karangan mahasiswa ASEAN Studies meliputi referensi, elipsis, dan konjungsi. Papaparan data penggunaannya adalah sebagai berikut.

\section{a. Referensi}

Berdasarkan kegiatan analisis data, dalam karangan bahasa Indonesia mahasiswa ASEAN Studies ditemukan ada dua jenis penggunaan referensi yaitu referensi anafora dan katafora. Paparan data penggunaan referensi yang ditemukan dalam analisis data contohnya sebagai berikut.

"... Pada tanggal 25, saya dan keluarga pergi melihat masjid Krue Se karena disini terjadi tempat yang populer, dan orang semua suka photo disini (20). Waktu siang, kami pergi ke masjid Pattani (21). Di masjid Pattani terjadi tempat yang indah sekali (22)." (NO/TH/01-22/PK1.Rf.an)

Kata "di sini" pada kutipan NO/TH/01-22/PK1.Rf.an tersebut memiliki anteseden yang terletak pada proposisi sebelumnya yaitu "masjid Krue Se", maka dari itu dua kalimat tersebut dihubungkan oleh referensi anafora.

Ada pun contoh penggunaan referensi katafora yang ditemukan dalam analisis data adalah sebagai berikut.

"Hari ini saya dan teman-teman Pergi ke kiri-wong (1). hari ini yaitu hari minggu (2). Cuaca Panas sekali. Saya dan teman-teman Perjalanan dari universitas walailak sampai kiri-wong waktu 45 menit (3)." (NA/TH/01-04/PK1.Rf.kt)

Pada penggalan teks kewacanaan berkode NA/TH/01-04/PK1.Rf.kt terdapat unsur deiktis "ini" yang melekat pada "hari ini" dijelaskan oleh informasi pada kalimat berikutnya. Pada kalimat yang ditulis setelah kalimat yang terdapat unsur penanda demonstrativa "hari ini" dijelaskan bahwa "hari ini yaitu hari minggu".

\section{b. Elipsis}

Dalam kegiatan analisis data karangan bahasa Indonesia mahasiswa ASEAN Studies ditemukan bentuk penggunaan elipsis dalam tataran lain (selain nominal, verbal, dan klausal) serta elipsis kausal. Bentuk-bentuk penggunaan elipsis tersebut dapat dilihat dari kutipan berikut ini. 
"Saya akan menulis tentang tarik wisata yang saya pernah wisata (1). Tarik wisata yang akan menulis adalah hua hin provinsi prachuabkihirikan (2). Saya pergi ke di sana pada tanggal 8 sampaia bulan Februari (3). Saya pergi ke prachuabkhirikhan oleh mobil ayah (4). Saya berangkat ø jam 1 malam (5)." (ND/TH/01-05/PK1.El.tl)

Elipsis yang terdapat pada kutipan berkode ND/TH/01-05/PK1.El.tl tersebut juga merupakan elipsis tataran lain (selain ellipsis nomina, verbal, dan klausal), ditandai dengan pelesapan frasa "ke prachuabkhirikhan" yang terdapat pada kalimat (4) menjadi kalimat (5) yang berbunyi "Saya berangkat $\emptyset$ (ke prachuabkhirikhan) jam 1 malam."

"Minggu lalu saya melakukan perjalanan ke Surat Thani (1). Ø Untuk membuat paspor (2). Saya perjalanan dari Walailak Universitas sampai Surat Thani pukul 07:30 (3). Setelah itu saya mampir makan bubur di sebelah samping jalan (4).

Setelah itu saya pergi ke kantor paspor Surat Thani (5). Tapi kantor paspor buka pukul 08:30 (6). Saya tunggu di balai

depan kantor paspor (7)." (WA/TH/01-03/PK1.El.kl)

Pada kutipan tersebut tampak klausa "saya melakukan perjalanan ke Surat Tani" yang terdapat pada kalimat pertama di lesapkan ketika menulis kalimat ke dua yang berbunyi "Ø (saya melakukan perjalanan ke Surat Thani) untuk membuat paspor."

c. Konjungsi

Dalam analisis data penggunaan piranti kohesi berupa konjungsi paling banyak ditemukan. Dalam menulis karangannya mahasiswa ASEAN Studies menggunakan piranti konjungsi dengan berbagai makna, meliputi: makna penambahan, makna keragu-raguan, makna pengakhiran, makna sebab, makna perlawanan, dan makana urutan waktu. Berikut ini adalah paparan data contoh penggunaan konjungsi makna penambahan yang peneliti temukan.

"Saya tidak suka musim panas karena membuat kulit hitam (1). Selain itu pohon kemarau dan air kering (2)." (HA/TH/0102/PK1.Kj.pnb)

Keberadaan frasa "selain itu" pada kalimat (2) tersebut berfungsi untuk menambahkan informasi yang disampaikan pada kalimat sebelumya yaitu kalimat (1). Pada kalimat pertama dinyatakan bahwa penulis karangan tidak suka musim panas karena membut kulit hitam,kemudian pada kalimat kedua diawali konjungsi "selain itu" yang menandakan bahwa "pohon kemarau dan air kering" merupakan informasi tambahan dari "membuat kulit hitam" pada kalimat (1).

Penggunaan konjungsi makna keragu-raguan yang ditemukan dalam analisis data contohnya sebagai berikut.

"Hari sabtu, saya dengan pacar saya pergi ke I-Kai wihara, kami diberkati oleh biksu (1). Setelah itu kami pergi ke Central (2). Di Central Nakhon, pacar saya mau akan membeli Iyn tas untuk memberi ibunya (3). Kami berjalan-jalan kira-kira tiga jam (4)." (SY/US/04-07/PK.Kj.krg)

Kehadiran piranti konjungsi bermakna keragu-raguan pada kutipan berkode SY/US/04-07/PK.kj tersebut ditandai dengan kehadiran kata "kira-kira". Kata tersebut menunjukkan bahwa waktu jalan-jalan selama tiga jam lamanya pada kalimat (4) masih belum pasti atau diragukan.

Berikut ini adalah contoh penggunaan konjungsi makna pengakhiran yang ditemukan dalam analisis data.

"Saya akan ajak teman pergi wisata ke mana-mana saja (1). Lalu saya mencari tempat wisata (2). Tetapi setelah itu teman saya belum dijelaskan mau pergi wisata atau tidak (3). Akhirnya teman-teman yang dipergi wisata bersama saya adalah tiga orang, saya seorang menjadi empat orang dari sepuluh orang (4). Setelah itu saya dan teman-teman pergi wisata ke Bangkok dan lain-lain (5). Di dalam perjalanan sekali itu dimulai di Universitas Walailak pada sore hari jumat pergi ke kota (6)." (NR/TH/07-12/PK1.Kj.akh)

Kehadiran penanda konjungsi "akhirnya" pada kalimat keempat menunjukkan bahwa kalimat ketiga merupakan pernyataan pengakhiran dari proposisi yang terkandung pada kalimat sebelumnya.

Penggunaan konjungsi makna sebab dapat ditunjukkan oleh kutipan berikut ini.

"Hari raya saya perki ke rumah saudara banyak (1). Dan setiap rumah akan mengangkat makanan kepada saya (2). Daging sapinya yang memotong di hari ini akan dimasakkan di semua rumah dan membagi kepada tetangga yang kita mau beri (3). Hari ini saya sangat senang karena dapat jumpa dengan keluarga yang lama tidak jumpa dan dapat kenalkan saudara yang tidak kenal (4)." (NI/US/19-22/PK1.Kj.sbb)

Konjungsi "karena" pada kutipan NI/US/19-22/PK1.Kj.sbb tersebut menghubungkan klausa "hari ini saya sangat senang" dengan klausa sebab "dapat jumpa dengan keluarga yang lama tidak jumpa dan dapat kenalkan saudara yang tidak kenal" sehingga paragraf tersebut dapat dikatakan mengandung penanda konjungsi makna sebab.

Dalam analisis data juga ditemukan penggunaan konjungsi makna perlawanan sebagai berikut.

" Tempat wisata yaitu Rajabhakti Park, Pantai Hua Hin, Hua Hin pasar, The Venezia Hua Hin, Hua Hin Samphannam pasar, Plearn Wan, The Cicada Market, Huahin Hills Vineyard dan wihara Huay mongkol tapi kami tidak bisa masuk setiap tempat karena tidak ada uang. Tempat kami bisa masuk yaitu Rajabhakti Park, Pantai HuaHin, Huahin Pasar, HuaHin Samphanam pasar, PlearnWan, The Cicada Market dan Wihara Huaymongkol." (NM/TH/15/PK1.Kj.plw)

Pada kalimat tersebut penulis karangan memberikan informasi bahwa di tempat wisata yang ia kunjungi terdapat banyak pilihan tempat yang menarik, namun penulis dan teman-temannya juga menyatakan bahwa tidak bisa masuk ke semua tempat itu karena tidak memiliki cukup uang, dan dua informasi bertentangan tersebut dihubungkan dengan konjungsi "tapi".

Ada pun contoh penggunaan konjungsi makna urutan waktu yang dapat ditemukan dalam analisis data adalah sebagai berikut. 


\begin{abstract}
"Saya dan keluarga berjalan-jalan ke Pattani 5 hari (1). Mulai tanggal 23 bulan April (2). Saya dan keluarga pergi ke Pattani (3). Hari pertama, kami bangun tidur pukul lima pagi (4). Ketika mandi dan berganti pakaian Selesai, kami berjalan-jalan ke Pattani (5). Waktu jam sore kemudian tiba di Pattani. Kami pergi ke rumah saudara (6). Di rumah saudara (7). Saya mandi (8). Setelah itu, jam tiga sore kami pergi ke pantai Taluksamika (9). Di tempat pantai Taluksamika ini terjadi tempat yang populer, ada banyak makanan dan enak (10). Saya dan saudara naik banana boat dan bermain air laut (11). Setelah itu kami pergi ke pasar malam dan makan malam (12). Hari yang kedua, tanggal 24 waktu pagi kami berangkat ke pasar palas untuk membeli barang-barang (13). Setelah itu, kami pergi ke air terjun Saikhan (14)." (NO/TH/01-14/PK1.Kj.wkt)
\end{abstract}

Penggunaan konjungsi makna urutan waktu pada kutipan nomor 10 ditandai dengan hadirnya kata "mulai" pada kalimat kedua. Kata "mulai" tersebut menghubungkan proposisi pada kalimat pertama dengan kalimat-kalimat setelah kalimat pertama dalam satu rangkaian urutan waktu. Kalimat kedua yang berbunyi "Mulai tanggal 23 bulan April" yang diikuti oleh kalimat ketiga "Saya dan keluarga pergi ke Pattani", menunjukkan bahwa perjalanan 5 hari ke Pattani yang dilakukan oleh penulis karangan dimulai pada tanggal 23 bulan April. Pada kalimat keempat penulis karangan memunculkan penanda konjungsi urutan waktu yaitu "hari pertama" yang menginformasikan kegiatan di hari pertama dari 5 hari perjalanannya.

Pada kalimat kelima diawali dengan konjungsi "Ketika mandi dan berganti pakaian Selesai" meskipun dalam bahasa Indonesia konjungsi "ketika" biasanya digunakan untuk menggabungkan dua peristiwa yang terjadi secara bersamaan namun pada paragraf tersebut konjungsi berupa "ketika" menunjukkan hubungan urutan waktu karena diikuti oleh kalimat yang menunjukkan aktivitas lanjutan dari aktivitas yang diinformasikan pada anteseden sebelumnya. Rangkaian urutan waktu tersebut terus berlanjut sampai kalimat (14) dan ditandai dengan konjungsi "setelah itu".

\title{
2) Piranti Kohesi Leksikal
}

Bentuk-bentuk penggunaan piranti kohesi leksikal dalam karangan mahasiswa ASEAN Studies meliputi reiterasi dan kolokasi. Papaparan data penggunaannya adalah sebagai berikut.

\section{a. Reiterasi (perulangan)}

Dalam analisis data peneliti menemukan penggunaan reiterasi berupa reiterasi penuh dan reiterasi menggunakan bentuk lain. Betuk penggunaan tersebut seperti pada kutipan berikut.

" ... Setelah itu, jam tiga sore kami pergi ke pantai Taluksamika (9). Di tempat pantai Taluksamika ini terjadi tempat yang populer, ada banyak makanan dan enak (10). Saya dan saudara naik banana boat dan bermain air laut (11). Setelah itu kami pergi ke pasar malam dan makan malam (12)." (NO/TH/01-12/PK1.Rt.pnh)

Frasa "pantai Taluksamika" yang muncul pada kalimat (9) diulang secara penuh pada kalimat (10).

Pengulangan-pengulangan itu menghasilkan makna utuh dalam wacana tersebut.

Bentuk penggunaan reiterasi atau pengulangan dengan bentuk lain diwakili oleh kutipan berikut ini.

"Setiap liburan semester saya dan Bagas akan berlibur (1). Saya dan Bagas berlibur ke Kra-bii bulan yang lalu (2). Kami sangat senang (3). Liburan semester ini juga, kami akan berlibur sekali (4). Dalam percakapan tadi saya dan Bagas berencana untuk berlibur mengunjungi Japan (5)." (SY/TH/10-14/PK1.Rt.bl)

Pada kutipan nomor tersebut terdapat kata "liburan" pada kalimat (1) kemudian diulang dengan konstruksi "berlibur" pada proposisi selanjutnya. Kata "berlibur" termasuk kata kerja yang berasal dari kata dasar yang sama dengan "liburan" yaitu "libur".

\section{b. Kolokasi}

Bentuk penggunaan kolokasi yang ditemukan dalam analisis data contohnya seperti berikut ini.

"... Setelah itu saya jalan ke pasar Ladyai (7). Di pasar Ladyai banyak orang dan banyak makanan (8). Yang ada banyak lagi kain baju (9). Saya membeli baju dan sepatu (10). Kemudian saya kembali ke hotel (11). Hari ini saya senang sekali (12)." (AM/TH/16-27/PK1.Kl).

Pada kutipan nomor 13 terdapat kata "pasar Ladyai" pada kalimat (7), kemudian pada kalimat (8) dijelaskan bahwa di pasar tersebut terdapat "banyak orang" dan "banyak makanan" serta diikuti dengan munculnya kata "membeli" pada kalimat (10). Keempat kata tersebut memiliki hubungan kolokasi karena sudah menjadi pengetahuan umum bahwa pasar adalah tempat orang berkumpul untuk melakukan kegiatan jual beli maka ketika ada kata "pasar" dalam pikiran kita kata tersebut selalu identik dengan kata banyak orang, banyak makanan, dan membeli. Kehadiran kata-kata yang berkolokasi tersebut dapat memberikan konstribusi pada pendekatan makna kata yang dirujuk yaitu "pasar Ladyai" pada kalimat (7).

\section{Paparan Piranti Koherensi yang Terdapat pada Karangan Bahasa Indonesia Mahasiswa ASEAN Studies Universitas Walailak}

1) Koherensi karena Kehadiran Piranti Kohesi

Kohesi merupakan salah satu faktor yang menjadikan sebuah wacana menjadi koheren. Berikut ini data-data penggalan teks kewacanaan yang koheren disebabkan kehadiran piranti kohesi.

a. Koheren Karena Kehadiran referensi

11 | BASINDO : Jurnal Kajian Bahasa, Sastra Indonesia, dan Pembelajarannya 
berikut.

Salah satu bentuk koherensi yang ditemukan dalam analis data karena penggunaan referensi adalah sebagai

"Perkenalkan, nama saya Thasneem Jehteh (1). Dan saya ada nama Indonesia adalah Nimas Ayu, saya suka nama

Indonesia itu (2)." (NI/TH/01-02/PK2.KK1)

Penggunaan piranti kohesi berupa referensi yang ditandai dengan kata tunjuk "itu" dengan anteseden terletak sebelumnya yaitu "nama Indonesia adalah Nimas Ayu" menjadikan penggalan teks kewacanaan ini padu secara keseluruhan. Kehadiran referensi tersebut juga menjadikan seluruh proposisi dalam penggalan teks kewacanaan tersebut membahas satu topik yang sama atau tidak keluar dari topik pembicaraan.

\section{b. Koheren karena Kehadiran Konjungsi}

Bentuk penggunaan konjungsi yang menyebabkan koherensi wacana adalah sebagai berikut.

" Hari sabtu, saya dengan pacar pergi ke I-Kai wihara, kami diberkahi oleh biksu (1). Setelah itu, kami pergi ke Central (2).

Di Central Nakhon, Pacar saya akan mau membeli Iyn tas untuk memberi ibunya (3)." (SY/US/04-06/PK2.KK1.Rtt)

Hadirnya konjungsi "setelah itu" menjadikan ide-ide dalam penggalan teks kewacanaan tersebut tersusun runtut. Apabila konjungsi "setelah itu" dihilangkan maka ide-ide dalam penggalan teks kewacanaan tersebut akan tampak melompat-lompat.

c. Koheren karena Kehadiran Reiterasi

" Hari itu saya dengan adik duduk di perahu untuk pergi jalan-jalan di pulau (1). Di pulau itu ada alam indah (2). Saya tinggal di pulau kira-kita 3 jam (3)." (HA/TH/23-25/PK2. KK1.tkt)

Pengulangan kata "pulau" secara penuh pada setiap kalimat, menjadikan penggalan teks kewacanaan ini memiliki susunan ide yang tidak keluar dari pembicaraan utama.

d. Koheren karena Kehadiran Lebih dari Satu Jenis Piranti Kohesi

"Saya akan menulis tentang perjalanan saya dan teman-teman ke Krabi (1). Perjalanan itu pada tahun lalu (2). Pagi jumat kami naik van di Universitas Walailak (3). Setelah itu kami turun di Terminal Nakhonsithammarat (4). Ketika sudah tiba saya dan teman-teman pergi ke toko makanan untuk makan siang (5). Toko itu ada banyak makanan yang enak (6)." (YU/TH/01-06/PK2.KK1)

Keberadaan piranti kohesi berupa referensi yaitu "perjalanan itu" yang merujuk pada "perjalanan saya dan teman-teman" secara anafora, dan "toko itu" yang merujuk pada "toko makanan" secara anafora, serta konjungsi makna urutan waktu "setelah itu", dan "ketika sudah tiba" membantu kalimat tersusun secara runtut dan tidak keluar dari topik pembicaraan.

"Pada tanggal 23 Januari 2016, saya dan teman pergi ke Kiriwong (1). Hari itu adalah hari liburan dari saya dan teman (2). Pada hari itu saya dan teman bangun jam tujuh (3). Setelah itu saya mandi dan berdandan, setelah itu saya pergi ke kantin untuk makan nasi pagi (4). Setelah itu, saya dan teman berangkat jam delapan tiga puluh (5). Saya pergi ke Khiriwong oleh sepeda motor (6). Perjalanan dari Universitas Walailak ø kira-kira 1 jam (7). Saya sampai di Khiriwong jam sembilan empat puluh lima (8)." (MI/TH/04-11/PK2. KK1.rtt.tkt)

Penggunaan piranti kohesi berupa referensi konjungsi urutan waktu, dan elipsis menjadikan ide-ide tersusun secara runtut, dan tidak keluar dari topik pembicaraan.

"Hari sabtu, saya dengan pacar saya pergi ke I-Kai wihara, kami diberkati oleh biksu (1). Setelah itu kami pergi ke Central (2). Di Central Nakhon, pacar saya mau akan membeli Iyn tas untuk memberi ibunya (3). Kami berjalan-jalan kira-kira tiga jam (4)." (SY/US/04-07/PK2.KK1.rtt.tkt)

Penggunaan konjungsi urutan waktu "setelah itu", serta pengulangan nama tempat "Central" secara penuh, menjadikan ide-ide dalam penggalan teks kewacanaan tersusun runtut dan tidak keluar topik pembicaraan.

e. Koheren karena Hubungan Parataksis

Hubungan parataksis yang terdapat dalam penggalan teks kewacanaan karangan mahasiswa ASEAN Studies yang ditemukan dalam analisis data adalah hubungan subordinatif sebagai berikut.

"Saya dan teman-teman menghabiskan dua hari di Krabi (1). Krabi adalah kota dengan laut pantai yang indah (2). Krabi adalah daya tarik banyak wisatawan (3). Krabi adalah tujuan wisata terkenal di Thailand (4). Perjalanan saya ke Krabi dengan teman-teman melewati kota Krabi untuk pergi ke Akomodasi (5). Akomodasi adalah sebuah resort kecil di pantai (6). Suasana tenang dan menyenangkan (7)." (FA/TH/06-12/PK2.sb)

Proposisi-proposisi seperti "kota dengan laut pantai yang indah", "tujuan wisata terkenal di Thailand", serta "suasana tenang dan menyenangkan" merupakan penjabaran dari "Krabi". Maka dari itu penggalan teks kewacanaan tersebut kohern karena adanya hubungan subordinatif.

\section{PEMBAHASAN}

Pembahasan Penggunaan Piranti Kohesi Gramatikal

1) Penggunaan Referensi 
Pada prisipnya referensi bergantung pada pemahaman menyeluruh terhadap lingkungan leksikogramatikal dari sebuah teks untuk menemukan gambaran utuh yang membentuk makna utuh dari sebuah kata atau struktur. Halliday dan Hasan (1976:31) menyatakan bahwa pada prinsipnya untuk mendapatkan gambaran secara penuh makna dari suatu kata atau struktur dalam penggunaan referensi perlu melakukan pemeriksaan pada insformasi yang ada di sekitar teks. Ketika referensi muncul dalam sebuah teks maka kalimat-kalimat yang tersusun dalam teks akan sulit bahkan tidak mungkin diartikan satu per satu, karena referensi sebagai piranti kohesi berperan untuk menjadikan bagian-bagian dari teks tersebut saling terkait. Nunan (1993:21) berpendapat bahwa referensi sebagai piranti kohesi memiliki peran khusus dalam menciptakan hubungan yang kohesif antara bagian-bagian yang sulit bahkan tidak mungkin untuk ditafsirkan apabila suatu kalimat keluar dari konteks.

Berdasarkan prinsip hubungan kohesi berupa referensi, penggunaan referensi yang ditemukan dalam analisis data sebenarnya tidak menyimpang dari prinsip referensi. Hanya saja, dalam analisis data ditemukan kesalahan pemilihan penanda referensi, yaitu penggunaan pronomina demonstrativa di sini, dan di situ, serta penggunaan pronomina persona jamak kita yang belum tepat. Arifin (2012:28) menyatakan bahwa perbedaan deiktis ini dan itu serta di sini dan di situ bergantung pada jarak penutur. Dalam KBBI di sini berarti kata penunjuk yang menyatakan tempat yang dekat dengan pembicara, sedangkan pada karangan mahasiswa demonstrativa tersebut digunakan untuk menunjuk sesuatu yang letaknya jauh. Dalam KBBI juga disebutkan makna di situ adalah kata penunjuk yang menyatakan tempat yang agak mendekat dengan pembicara, namun dalam kegiatan analisis data ditemukan demonstrativa di situ digunakan untuk merujuk tempat yang jauh dengan penulis karangan. Pronomina demonstrativa yang tepat digunakan untuk merujuk tempat yang jauh adalah di sana yang bermakna kata penunjuk untuk menyatakan tempat yang jauh dari pembicara.

Kata kita sebagai pronomina persona pertama jamak dalam bahasa Indonesia digunakan ketika mitra tutur juga ikut terlibat. Kentjono, Datang, Suhardiyanto, dan Candrani (2010:178) menyatakan bahwa kata ganti orang pertama kita bersifat inklusif karena mengikutkan orang yang diajak berbicara. Akan tetapi dalam analisis data, kata kita digunakan untuk merujuk saya (selaku penulis karangan) dan teman-teman yang terlibat dalam kegiatan wisata yang dilakukan penulis, sedangkan pembaca tidak terlibat dalam kegiatan tersebut. Maka dari itu penggunaan kita dalam karangan tersebut menjadi tepat apabila diganti dengan kami. Kentjono, Datang, Suhardiyanto, dan Candrani (2010:178) berpendapat kata ganti orang pertama kami bersifat eksklusif, artinya kata ganti tersebut tidak mengikutkan orang yang diajak bicara.

Kerancuan penggunaan kata ganti kita dengan kami tersebut disebabkan dalam bahasa Thailand penggunaan kata ganti orang pertama jamak tidak dibedakan mana yang bersifat inklusif atau pun yang bersifat eksklusif. Dalam kamus Podjananukrom pasa Indonesia-Thai leh pasa Thai-Indonesia baik kata kami ataupun kita memiliki arti yang sama yaitu rao. Kebiasaan dalam menggunakan kata ganti tersebut terbawa ketika pebelajar BIPA asala Thailand belajar bahasa Indonesia.

\section{2) Penggunaan Elipsis}

Penggunaan elipsis dalam karangan mahasiswa Walailak ditandai dengan pelesapan kata yang mengandung preposisi (elipsis tataran lain) serta pelesapan klausa (elipsis klausal). Kalimat-kalimat yang terdapat unsur yang dilesapkan itu masih berhubungan dengan kalimat yang dituliskan sebelumnya.

Elipsis tataran lain yang digunakan dalam karangan mahasiswa berupa pelesapan frasa yang mengandung preposisi seperti ke khiriwong, dan ke prachuabkhirikhan. Penggolongan ke dalam elipsis tataran lain tersebut berdasarkan pendapat Arifin (2012:42) bahwa yang dimaksud elipsis tataran lain adalah elipsis selain nomina, verba, dan klausa. Penggolongan tersebut juga dikarenakan frasa ke khiriwong dan frasa ke prachuabkhirikhan bukan lah termasuk pada frasa verba atau nomina, dan juga belum sampai pada tataran klausa, sehingga tidak dapat digolongkan ke dalam jenis elipsis verbal, elipsis nominal, atau elipsis klausal. Frasa ke khiriwong dan frasa ke prachuabkhirikhan merupakan frasa preposisional yang terdiri dari preposisi dan nomina, hadirnya ke pada frasa tersebut menunjukkan hubungan arah, seperti yang ditulis oleh Muslich (2010:108) bahwa preposisi ke untuk hubungan arah menuju suatu tempat.

Penggunaan elipsis klausal ditandai dengan pelesapan klausa saya melakukan perjalanan ke Surat Tani. Penggolongan elipsis tersebut dalam elipsis klausal sesuai dengan definisi elipsis klausal yang dinyatakan oleh Halliday dan Hassan (dalam Arifin, 2010:41) bahwa elipsis klausal adalah pelesapan klausa seluruhnya ataupun sebagian.

\section{3) Penggunaan Konjungsi}

Dalam penggunaan konjungsi yang menandakan hubungan penambahan, ditemukan penggunaan kata dan, selain itu, juga sebagai penanda hadirnya konjungsi makna penambahan. Pemilihan tiga kata tersebut sebagai penanda konjungsi makna penambahan sesuai dengan pendapat Arifin (2012:60) bahwa piranti konjungsi yang bersifat tambahan antara lain pula, selanjutnya, dan, di samping itu, tambahan lagi, dan selain itu. Rani, Martutik, dan Arifin (2013:146) juga menyebutkan hal yang sama bahwa piranti konjungsi tambahan antara lain: pula, juga, selanjutnya, dan, di samping itu, tambahan lagi, dan selain itu.

Pada prinsipnya konjungsi penambahan dapat terjadi apabila proposisi yang yang dirangkaikan untuk memberi tambahan keterangan terhadap proposisi sebelumnya, seperti yang ditulis oleh Halliday dan Hassan (dalam Suswati, Sujatna, dan Mahdi, 2014:16) bahwa "additive conjunctions simply add more information to what is already there" atau konjungsi penambahan menambahkan informasi pada informasi yang sudah ada.

Konjungsi dubitatif yang muncul dalam karangan mahasiswa Walailak ditandai dengan kata kira-kira dan mungkin. Dalam Kamus Besar Bahasa Indonesia kira berarti 'pendapat yang hanya berdasarkan dugaan atau perasaan', sedangkan mungkin berarti 'tidak atau belum tentu' . Oleh karena itu, kata mungkin dan kira-kira tepat 
digunakan sebagai penghubung proposisi yang masih diragukan, sesuai dengan pendapat Rani, Martutik, dan Arifin (2013: 153) yang menyatakan bahwa piranti dubitatif digunakan untuk mengantarkan bagian yang masih menimbulkan keraguan.

Dalam karangan mahasiswa juga ditemukan penggunaan konjungsi yang menyatakan pengakhiran dari proposisi-proposisi sebelumnya. Konjungsi makna pengakhiran ditandai dengan kata akhirnya. Penggunaan akhirnya sebagai konjungsi makna pengakhiran dalam karangan bahasa Indonesia mahasiswa Walailak sudah sesuai karena akhirnya memiliki arti 'kesudahannya' dan mahasiswa meletakkannya sebelum proposisi yang menyatkan akhir dari proposisi-proposisi sebelumnya. Selain itu, penggunaan kata akhirnya sebagai penanda konjungsi pengakhiran juga didukung oleh pendapat Arifin (2010:65) yang menyatakan bahwa konjungsi yang menyatakan makna pengakhiran jika kalimat yang mengandung konjungsi itu menyatakan pengakhiran dari proposisi yang terkandung dalam kalimat sebelumnya, beliau juga menyebutkan salah satu konjungsi yang bermakna pengakhiran adalah akhirnya.

Untuk menyatakan hubungan sebab, mahasiswa menggunakan konjungsi karena sebelum kalimat yang menyatakan sebab dari proposisi-proposisi sebelumnya. Penggunaan konjungsi tersebut sudah tepat karena dalam penggunaan tersebut mahasiswa menggunakan konjungsi untuk mengawali kalimat yang menyatakan sebab dari kalimat-kalimat sebelumnya. Penggunaan tersebut sesuai dengan pendapat Arifin (2012:61) yang menyatakan bahwa konjungsi yang menyatakan makna 'sebab' jika kalimat yang mengandung konjungsi itu menyatakan sebab dari pernyataan yang terkandung dalam kalimat sebelumnya. Selain itu, pemilihan karena sebagai penanda konjungsi sebab sudah tepat. Menurut Muslich (2010:114) karena termasuk dalam konjungsi subordinatif penyebab selain sebab dan oleh karena.

Konjungsi makna perlawanan muncul dengan ditandai hadirnya kata tapi untuk menghubungkan dua proposisi yang saling bertentangan. Dalam penggunaan konjungsi makna perlawanan tersebut mahasiswa ASEAN Studies meletakkan penanda konjungsi tapi pada kalimat yang menyatakan perlawanan dari proposisi yang terkandung dalam kalimat sebelumnya. Penggunaan kata tapi sebagai penanda penggunaan konjungsi makna perlawanan sesuai dengan pendapat Arifin (2012:66) yang menyebutkan konjungsi antarkalimat yang menyatakan makna penjelasan antara lain tetapi, akan tetapi, namun, sebaliknya, anehnya, sayangnya. Penggunaan konjungsi perlawanan tersebut juga didukung oleh Muslich (2010:116) yang menyatakan bahwa tetapi, akan tetapi, dan namun merupakan penanda konjungsi antarkalimat yang menyatakan pertentangan dengan keadaan sebelumnya.

Konjungsi makna urutan waktu yang digunakan mahasiswa dalam menceritakan peristiwa yang berupa tahapan atau urutan waktu berupa kemudian, sesudah, setelah itu, sesudah selesai, ketika, serta menyebutkan nama hari atau waktu. Menurut Rani, Martutik, dan Arifin (2013:134) urutan waktu dapat dimulai dari proposisi yang menunjukkan tahap awal dan dilanjutkan oleh tahap berikutnya. Ditemukan ketidaktepatan pemilihan penanda konjungsi, yaitu penggunaan "ketika" yang merupakan penanda hubungan kebersamaan dalam bahasa Indonesia sebagai konjungsi untuk menhubungkan peristiwa yang berurutan. Menurut Muslich (2010:163) ketika merupakan subordinator yang dipakai dalam hubungan waktu bersamaan. Oleh karena itu penggunaan ketika sebagai konjungsi makna urutan waktu sebaiknya diganti dengan sesudah, setelah itu, kemudian, atau yang lainnya yang termasuk dalam subordinatif hubungan waktu berurutan.

\section{Pembahasan Penggunaan Piranti Kohesi Leksikal}

1) Penggunaan Reiterasi (Perulangan)

Reiterasi (perulangan) yang ditemukan dalam kegiatan analisis data yang pertama adalah perulangan penuh yakni mengulang seluruhnya dengan bentuk yang sama, kedua perulangan dengan bentuk lain, berupa perulangan kata yang berasal dari kata dasar yang sama menjadi bentuk yang berbeda.

Bentuk penggunaan reiterasi berupa perulangan penuh tersebut contohnya pengulangan kata memasak, pagi, pergi, dan frasa Pantai Taluksamika secara penuh pada kalimat-kalimat lanjutan tanpa pengurangan dan perubahan bentuk. Penggunaan ulangan penuh tersebut sesuai dengan pendapat Rani, Martutik, dan Arifin (2013:159) yang menyatakan bahwa ulangan penuh berarti mengulang satu fungsi dalam kalimat secara penuh, tanpa pengurangan dan perubahan bentuk.

Bila ditinjau dari pembagian jenis reiterasi yang dikemukakan oleh Tanskanen penggunaan reiterasi yang mengulang kata atau frasa secara penuh tanpa perubahan apa pun tersebut termasuk ke dalam penggunaan perulangan sederhana. Tanskanen (dalam Boček, 2016:11) menyatakan bahwa perulangan sederhana tidak menggunakan kata yang berbeda untuk merujuk pada proposisi yang terdahulu dan hanya boleh menggunakan sedikit perubahan gramatikal.

Bentuk penggunaan reiterasi berupa perulangan dengan bentuk lain ditunjukkan dengan munculnya kata liburan yang kemudian pada kalimat selanjutnya diulang dengan bentuk lain yaitu berlibur. Penggolongan reiterasi berupa perulangan dengan bentuk lain tersebut juga berdasarkan pendapat Rani, Martutik, dan Arifin (2013:160) yang menyatakan bahwa ulangan dengan bentuk lain terjadi apabila sebuah kata diulang dengan konstruksi atau bentuk kata lain yang masih mempunyai bentuk dasar yang sama.

\section{2) Penggunaan Kolokasi}

Kolokasi dalam karangan mahasiswa Walailak ditandai dengan penyebutan kosa kata-kosa kata yang memiliki makna berdekatan dengan kata yang dijadikan sebagai rujukan pada proposisi-proposisi yang dituturkan berikutnya. Contoh yang ditemukan dalam analisis data adalah kata Pasar Ladyai memiliki kedekatan dengan frasa banyak orang, banyak makanan, dan kata membeli. Contoh lainnya adalah cuaca panas identik dengan mata hari cerah, dan cuaca hujan yang dekat dengan pakaian basah. 
Pengategorian kata-kata yang memiliki makna berdekatan terseut sebagai penggunaan piranti kohesi berupa kolokasi berdasarkan pada pendapat Ebrahimpourtaher dan Eissaei (2013:64) yang menyatakan bahwa kolokasi terjadi karena adanya unsur bahasa yang saling berasosiasi secara teratur. Rani, Martutik, dan Arifin (2013:163) berpendapat bahwa suatu hal yang selalu berdekatan atau berdampingan dengan yang lain biasanya diasosiasikan sebagai satu kesatuan. Adanya satu kesatuan makna tersebut menyebabkan mitra tutur atau pembaca secara psikologis menarik suatu kesimpulan kolokasi. Behnam (dalam Ebrahimpourtaher dan Eissaei, 2013:64) menyatakan bahwa kolokasi merupakan salah satu faktor yang membangun ekspektasi mitra tutur atau pembaca terhadap informasi apa yang akan disampaikan selanjutnya oleh penutur. Dengan demikian adanya kolokasi membantu pembaca memprediksikan informasi apa yang akan muncul selanjutnya, begitu juga dengan penggunaan kolokasi yang ditemukan dalam kegiatan analisis data.

\section{Pembahasan Penggunaan Koherensi}

Koherensi yang terdapat dalam karangan mahasiswa ASEAN Studies adalah koherensi yang disebabkan oleh hadirnya piranti kohesi dan karena adanya hubungan parataksis dalam sebuah penggalan teks kewacanaan. Koherensi yang terjadi karena kehadiran kohesi adalah hal yang wajar, karena kohesi merupakan salah satu unsur yang menjadikan sebuah wacana koheren. Dardjowidjojo (1992:343) menyatakan bahwa kohesi adalah keserasian hubungan antara unsur yang satu dengan unsur yang lain dalam wacana sehingga terciptalah pengertian yang apik atau koheren. Meskipun demikian, tidak semua data penggalan teks kewacanaan yang terdapat penggunaan piranti kohesi di dalamnya pasti kohern karena mempertimbangkan keruntutan dan kelogisan penyusunan ide-ide dalam wacana, serta ide-ide dalam keseluruhan penggalan teks kewacanaan tetap dalam satu topik. Koherensi yang terjadi karena hubungan parataksis sesuai dengan pendapat rentel yang dikutip oleh Arifin (2012:17) bahwa koherensi dapat diciptakan dengan menggunakan bentuk-bentuk yang mempunyai hubungan parataksis dan hipotaksis.

Dalam sebuah penggalan teks kewacanaan memungkinkan hadir lebih dari satu jenis piranti kohesi. Kehadiran beberapa jenis kohesi tersebut dapat saling mendukung untuk membentuk koherensi wacana. Beberapa jenis kohesi yang hadir dalam wacana tersebut menjadikan ide-ide dalam wacana tersusun runtut, logis, dan tidak keluar dari topik pembicaraan. Susunan ide yang runtut, logis, dan tidak keluar dari topik pembicaraan dapat menjadi faktor yang menyebabkan koherensi wacana tersebut sesuai dengan pendapat Arifin (2012:19) yang menyatakan bahwa koherensi wacana dapat dibentuk dengan menyusun ide-ide secara runtut, logis, dan tidak keluar dari topik pembicaraan.

Hubungan parataksis sebagai faktor pembentuk koherensi yang ditemukan dalam kegiatan analisis data berupa penggalan teks kewacanaan yang mengandung gagasan subordinatif. Hadirnya gagasan yang subordinatif tersebut ditandai dengan penyebutan ide yang memiliki makna lebih luas di awal, kemudian diikuti dengan penyebutan ide yang lebih sempit dan masih tercakup dalam ide yang lebih luas yang telah disebutkan di awal tersebut. Penggunaan tersebut sesuai dengan pendapat Rentel (dalam Arifin, 2012:18) bahwa penataan subordinatif berarti menata ide dengan menempatkan ide yang lebih luas cakupan maknanya di awal dan diikuti oleh ide yang lebih sempit yang tercakup.

\section{PENUTUP}

\section{Simpulan}

Berdasarkan hasil dan pembahasan yang telah dipaparkan, dapat diperoleh dua simpulan. Pertama, mahasiswa ASEAN Studies menggunakan beragam piranti kohesi dalam menulis karangan. Piranti kohesi tersebut berupa piranti kohesi gramatikal yaitu, referensi anafora, referensi katafora, elipsis, dan konjungsi, serta piranti kohesi leksikal berupa reiterasi dan kolokasi. Dalam data penggunaan referensi ditemukan kerancuan penggunaan kata deiktis di sini, di sana dan di situ. Mahasiswa juga rancu dalam menggunakan pronomina persona jamak kami dengan kita. Pada penggunaan konjungsi juga terdapat kesalahan pemilihan kata ketika sebagai penanda urutan waktu. Kedua, mahasiswa ASEAN Studies membentuk koherensi dalam karangannya dengan menghadirkan piranti kohesi, serta memunculkan hubungan parataksis yang ditunjukkan dengan penataan gagasan secara subordinatif.

\section{Saran}

Berdasarkan hasil simpulan yang didapatkan dari kegiatan penelitian ini, peneliti memberikan saran kepada pengajar BIPA untuk menyusun Rencana Pelaksanaan Pembelajaran (RPP) yang sesuai dengan kebutuhan dan kemampuan pebelajar tingkat madya asal Thailand. pengajar BIPA disarankan untuk memberikan penekanan lebih terhadap ketepatan penggunaan piranti kohesi khususnya dalam menggunakan konjungsi urutan waktu saat kegiatan pembelajaran menulis bahasa Indonesia. Penegasan penggunaan pronomina persona jamak seperti kami dan kita juga harus diperhatikan. Selain itu pengajar juga dituntut untuk memberikan contoh-contoh penggunaan piranti kohesi dengan penanda yang lebih beragam agar pebelajar BIPA asal Thailand dengan tingkatan madya mampu menulis dengan kohesif dan koheren.

\section{DAFTAR RUJUKAN}

Arifin, Bustanul. 2012. Alat Kohesi Wacana Bahasa Indonesia. Malang: Gunung Samudra.

Boček, Stepan Bc. 2016. Lexical Cohesion in Stephen King's Short Stories. Tesis tidak diterbitkan. Ostrava: Universitasis Masyarikianae Brunensis.

Dardjowidjojo, Soenjono, Harimurti Kridalaksana, Anton M. Moeliono, Samsuri, Mangasa Silitonga, Bambang Kaswanti Purwo, W. H. C. M. Lalamentik, M. Ramlan, Sudaryanto, D. P. Tampubolon, Henry Guntur Tarigan. 1992. Tata Bahasa Baku Bahasa Indonesia. Jakarta: Balai Pustaka. 
Ebrahimpourtaher, Adel, dan Saeide Eissaei. 2013. Awareness of Lexical Cohesive Devices in Text and Reading Comprehension. International Journal of Educational Research and Technology, 4 (2): 63-65.

Halliday, M. A. K., dan Ruqaiya Hassan.1984. Cohesion in English. New York: Longman Inc.

Kentjono, Djoko, Frans Asisi Datang, Totok Suhardiyanto, Amalia Candrayani. 2010. Tata Bahasa Acuan Bahasa Indonesia untuk Penutur Asing. Jakarta: Wedatama Widya Sastra.

Kurniawan, Khaerudin. 2008. Pemartabatan Bahasa Indonesia sebagai Jati Diri Bangsa. Widyaparwa: Jurnal Ilmiah Kebahasaan dan Kesastraan, 36 (1): 1-19.

Muslich, Masnur. 2010. Garis-garis Besar Tatabahasa Baku Bahasa Indonesia. Bandung: PT. Refika Aditama.

Nunan, D. 1993. Introducing Discourse Analysis. London: Penguim.

Palmer, Juan Carlos. 1999. Coherence and Cohesion in the English Language Classroom: the Use of Lexical Reiteration and Pronominalisation. RELC Journal, 30 (2): 61-82.

Rani, Abdul, Bustanul Arifin, Martutik. 2013. Analisis Wacana Tinjauan Deskriptif. Malang: Surya Pena Gemilang.

Suswati, Susi, Eva Tuckyta Sari Sudjatna, dan Sutiono Mahdi. 2014. Additive Conjunction Choice in English Children Short Stories: a Syntactic and Semantic Analysis. International Journal of Language Learning and Applied Linguistics World, 5 (4): 11-21.

Waenawe, Wandah. 2013. Keefektifan Metode Diskusi Kelompok dan Bermain Peran dalam Meningkatkan Keterampilan Berbicara Bahasa Indonesia Mahasiswa Thammasat University, Thailand. Tesis tidak diterbitkan. Yogyakarta: Program Pasca Sarjana UNY. 